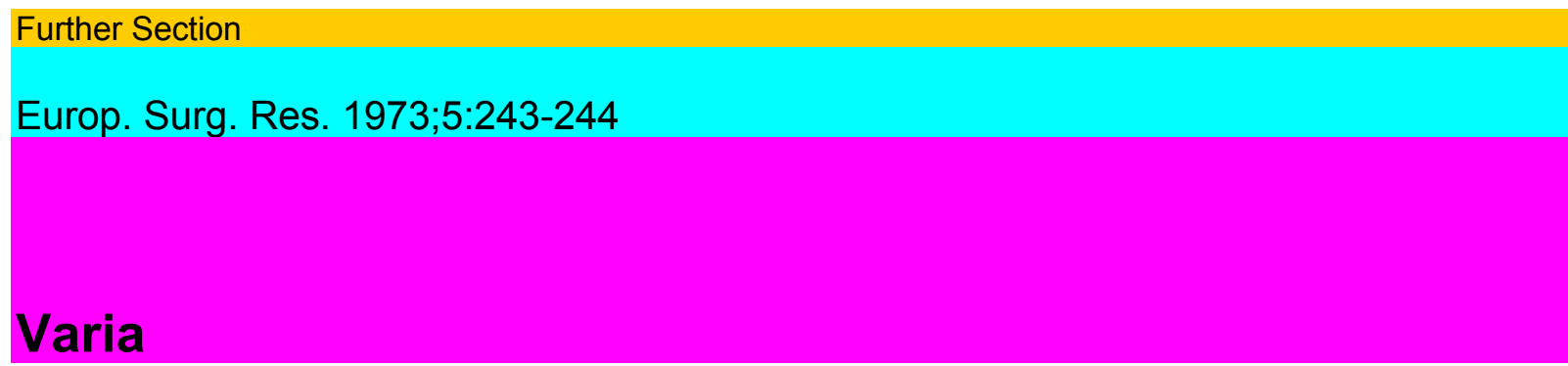

\title{
European Society for Experimental Surgery
}

The 9th Congress of the ESES will take place in Salzburg from May 14 to 17, 1974. The Organising Committee will do everything possible to make this Congress scientifically rewarding and a memorable social experience for all participants.

\section{Scientific Program}

The meetings will take place at the Kongresshaus located closely to the main hotels. The scientific program will be devoted to (1) Cardiogenic Shock; (2) Formation and Inhibition of Metastasis; (3) Transplantation and Immunology; (4) Portal Hypertension; (5) Organ Preservation and Cryobiology; (6) Surgery of the Biliary and Pancreatic Duct System; (7) Plastic and Reconstructive Surgery.

The program will include review lectures on the most important topics given by invited scientists, ten-minute presentations of papers submitted by participants, film sessions and exhibitions.

\section{Submission of Papers}

Those who want to present a paper must send an abstract in 5 copies, typed within one page of A4 format, double spaced with wide margin. The abstract should be headed by the name of the author(s) underlining the name of the speaker, the title of the paper and full mailing address of the institution from which the work originates. The abstract must be informative, stating the problems, the methods involved and giving a precise summary of the results.

\section{Deadline}

The abstracts must be in Salzburg before January 15, 1974. They should be addressed to the Organizing Committee, 9th Congress of the ESES, Ludwig Boltzmann-Institut für Exp. Chirurgie, Landeskrankenanstalten, A-5020 Salzburg (Austria).

\section{Social Program}

Social events include a reception given by the government of Salzburg, a Surprise Party at Hellbrunn Castle and a Banquet at Schloss Klesheim on May 17.

\section{Bluttransfusionskongress 1974 in Berlin}

Die Deutsche Gesellschaft für Bluttransfusion veranstaltet in der Kongresshalle Berlin vom 28. bis 31. Mai 1974 ihren 16. Kongress.

Das wissenschaftliche Programm wird folgende Hauptthemen umfassen: 1. Hä-motherapie nach Mass; a) Zellen (Schwerpunkt Thrombozyten und Leukozyten); b) Plasmafraktionen einschliesslich gerinnungsphysiologischer Substanzen. 2. Epide244

Varia

miologie und Blutspende. 3. Immunchemie (Antigene und Antikörper). 4. Stammzel-lentransplantationen. 5. Freie Vorträge. Ausserdem werden Kurse abgehalten: 1. HL-A Seminar. 2. Serologische Verträg-lichkeitsproben und deren Problematik, AKSuchtest. 3. Diagnostik der Gerinnung. 